\title{
Wayang Golek Menak: Wayang Puppet Show as Visualization Media of Javanese Literature
}

\author{
Trisno Santoso ${ }^{1}$ and Bagus Wahyu Setyawan ${ }^{2}$ \\ \{trisnopelok@yahoo.com¹, bagusws93@gmail.com²\} \\ ${ }^{1}$ Institut Seni Indonesia Surakarta, Indonesia \\ ${ }^{2}$ Universitas Sebelas Maret, Surakarta, Indonesia
}

\begin{abstract}
Puppet shows developing in Javanese culture is definitely various, including wayang kulit, wayang kancil, wayang suket, wayang krucil, wayang klithik, and wayang golek. This study was a developmental research, that developed Wayang Golek Ménak Sentolo with using theatre and cinematography approaches. Its aims to develop and create the new form of wayang golek sentolo show, Yogyakarta. The stages included conducting the orientation of wayang golek sentolo show, perfecting the concept, conducting FGD on the development concept, conducting the stage orientation, making wayang puppet protoype, testing the developmental product, and disseminating it in the show. After doing these stages, Wayang Golek Ménak Sentolo show gets developed from the original one, in terms of duration that become shorter, language using other languages than Javanese, show techniques that use theatre approach with modern blocking and lighting, voice acting of wayang figure with using dubbing techniques as in animation films, stage developed into portable to ease the movement as needed, as well as the form of wayang created differently from the original in terms of size and materials used. It is expected that the development and new form of wayang golek menak will get more acceptance from the modern community.
\end{abstract}

Keywords: wayang golek menak, development, puppet show, visualization media, Javanese literature, serat menak.

\section{INTRODUCTION}

Discussing about puppet shows in Java, there are two types of puppet shows, namely wayang golek and wayang krucil. Many people name wayang krucil as wayang klithik while wayang golek is called as wayang théling, wayang thengul, and wayang klithik is also occasionally known as wayang krucil and wayang thimlong [1]. These wayang are made from woods as the main material. Wayang golek is made from wooden blocks and wayang klithik is made from wooden boards. Their forms are similar to wayang kulit, but have the smaller size, and their hands are made from animal leathers. Moreover, wayang golek uses epic stories of Mahabarata, Ramayana, Serat Menak, Babad, and indigeneous fictions. Meanwhile, wayang klithik uses stories of Babad Majapahit, Serat Panji, and Serat Menak.

Puppet shows or wayang boneka also exist in some countries. In China, there is a puppet show combined with television broadcast and modern staging [2]. As a traditional art show, this 
puppet show is modified with modern stuff to make it keep being new and more attractive for the audiences. In United State of America, puppet shows are well known as Sesame Street [3]. The shows with using puppet are reflected as conventional art shows because they only rely on puppeteer's ability as the single artist in the show [4] [5]. It is due to that puppet shows are only popular between the end of the $19^{\text {th }}$ century and the beginning of the $20^{\text {th }}$ century, which is between in year of 2000-2005. Moreover, puppet shows then started to be shifted by modern arts, such as films, soap operas, cinemas, and some shows with using more modern technologies.

In Javanese community arts, especially Central Java, East Java, and Yogyakarta, there are puppet shows called as wayang with various types, such as wayang golek and wayang klithik. Wayang golek is developed in Bandung, Yogyakarta, Cirebon, Tegal, Pekalongan, Kebumen, Bojonegoro, and Lamongan, while wayang klithik is found in Blitar, Kediri, Nganjuk, Blora, and Klaten [6]. To stand wayang puppet on the stage, wayang golek show uses banana stems similar to wayang kulit show. Meanwhile, wayang klithik is place in the bamboo which have been punched. Besides, the other similar thing of wayang klithik and wayang kulit shows is not to use kelir or screen background. However, the height of banana stems for standing on wayang golek is higher than wayang kulit.

Moreover, wayang golek is the developmental type of puppet theatre with more complex form. The philoshophical and aesthetic values of wayang golek show is connected to the ones in wayang kulit purwa [8] [9]. The absolute difference between the shows is the form of wayang puppets. Wayang golek show uses three-dimensional puppets while wayang kulit uses flat or two-dimensional puppets. Besides, wayang golek show uses stories from serat Menak. Nevertheless, the use of serat Menak story is not absolute, wayang golek show occasionally uses Ramayana and Mahabharata stories.

Henceforth, this study deeply investigates wayang golek menak that obtains the story from Serat Menak by Yasadipura. Wayang golek menak is the development of wayang golek show and can be used as a medium to visualize and introduce Javanese literary works, particularly Serat Menak to the public. This is due to the current condition of Javanese literature becoming increasingly lack of people interest. Consequently, the reactualization effort is required to do to sincerely reintroduce Javanese literature to the community.

\section{METHODS}

This study was a developmental research, referring to the development of Wayang Golek Ménak Sentolo with using theatre and cinematography approaches. It aims to develop and to create the new form of wayang golek sentolo show, Yogyakarta. The stages of Wayang Golek Ménak Sentolo development adopted Gray \& Malins's theory [10]. They consist of the orientation of Wayang Golek Ménak Sentolo show, perfection of the concept, FGD on the development concept, orientation of the stage, creation of the wayang puppet prototype, developmental product test, and dissemination through the show, held in Gedung Teater Kecil, Insitut Seni Indonesia. After that, the seminar and FGD on the result of the new version of Wayang Golek Ménak Sentolo show involving some experts in wayang golek sentolo, staging, art show, and traditional art are conducted.

\section{RESULTS AND DISCUSSION}

Wayang golek menak is a new breakthrough for previous dalang (puppeteers) to keep delivering guidance in the show with a new style, but still using old equipments that are attributed to dalang in that era between $1950-1980^{\text {th }}$ [11]. The most notable thing of wayang golek show in Yogyakarta is reflected as a means of Islamic religion dissemination [12]. From 
the content of the story, dalang always suggest people to believe in Islamic lesson or the Prophet's religion. However, these shows have never been performed by dalang who are obedient to the Islamic Shari'a. Wayang golek dalang are similar to the ones of wayang kulit who still adhere the mixed lesson of Hinduism and Islam [13].

\subsection{Wayang Golek Menak Show Structure}

As one of the Javanese traditional arts, wayang golek show has a standard concensus, frequently called as 'pakem'. Pakem become the reference or guide that has to be followed by dalang in every Javanses traditional art show. If this pakem is not followed, the Javanese traditional art showed is considered to breach pakem or not merely the pure Javanese traditional art because it contains some development and innovations [14]. In fact, wayang golek menak show has pakem or some rules.

Similar to wayang kulit purwa, wayang golek menak is a puppet theatre developmental type with another form. This indicates that philoshopical and aesthetic values reflected in wayang golek menak show originally refers the wayang kulit show ones. The significant differences between wayang kulit purwa and wayang golek menak is represented by wayang puppet [15] and story. Wayang golek show uses three-dimensional puppet while wayang kulit use the flat or two-dimensional one, and wayang golek stories are taken from serat menak. Moreover, how wayang golek of serat menak show is performed is slightly similar to wayang kulit purwa show.

Wayang golek show also uses Javanese gamelan offbeat and various gending, ladrang, ketawang, srepeg, palaran, gangsaran, kemuda, etc., which is similar to wayang kulit show [16]. The show is strated with Talu gendhing. In addition, the structure of scenes in wayang golek show is not considerably different from wayang kulit show. The differences of the scene structure in wayang kulit and wayang golek menak shows are explained in the following table.

Table 1.

Wayang Kulit Purwa and Wayang Golek Menak Show Structure

\begin{tabular}{lll}
\hline No & Wayang Kulit Purwa & Wayang Golek Menak \\
\hline 1. & Jejer Kraton scene & Jejer Kraton scene \\
\hline 2. & Dayohan & Dayohan \\
\hline 3. & Bedholan Jejer scene & Bedholan Jejer scene \\
\hline 4. & Paseban Njawi scene & Paseban Njawi scene \\
\hline 5. & Perang Kembang scene & War scene \\
\hline 6. & Second Jejer scene & Second Jejer scene \\
\hline 7. & Budhalan Sabrang scene & Budhalan Sabrang scene \\
\hline 8. & Second War scene & Second War scene \\
\hline 9. & Gara-gara scene & Pathet Sanga scene \\
\hline 10 & Uluk-uluk scene & Perang Tandingan scene \\
\hline 11. & Perang Tandingan scene & Perang Brubuh scene \\
\hline 12. & Perang Brubuh scene & - \\
\hline
\end{tabular}

In general, wayang golek menak show refers to the consensus of the show in wayang kulit. Scenes in wayang kulit show divide into some parts, known as 'pathet'. There are three pathet used, namely pathet nem, pathet sanga, and pathet manyura. These pathet are used as references to increase the emotional level and conflicts in the story [17]. Gendhing or music 
accompaniment used in each pathet is also different. When dalang will change pathet, dalang will give sign and code with using 'suluk' or 'janturan' directly received by musicians [18].

The scene structure of wayang golek menak show is slightly similar to wayang kulit show. The initial scene in wayang golek menak show uses jejeran scene. Jejer scene in ringgit purwa is an initial performance because its function is to start the story. The intial scene of both wayang kulit purwa and wayang golek menak is ended by paseban njawi scene. Paseban njawi scene is signified by punggawa's (court official) meeting whom discussed about the King's instructions after the first jejer scene [19]. The difference is gara-gara scene. In wayang kulit purwa show, changing pathet sanga to pathet manyura is marked by gara-gara scene or the present of punakawan servants. In wayang golek menak show, gara-gara scene does not exist. This is because of that the background of story performed in wayang golek menak is orginally from Serat Menak in which punakawan figures do not exist.

\subsection{Wayang Golek Menak Story}

The source of wayang golek menak stories is Kitab Menak, written by Ki Carik Narawita, Waladana's son-in-law, in the name of Kanjeng Ratu Mas Blitar's will, the queen of Sunan Paku Buwana I, in 1717. It is wriiten on Friday, Rajab, 17th, tahun Dal, wuku Marakeh, mangsa Kasa, with sengkalan: Lenging welut rasa purun (1639 AJ or 1717 AD) [20]. Therefore, it can be concluded that wayang golek menak exists beween the end of the $18^{\text {th }}$ century and the beginning of the $19^{\text {th }}$ century. Wayang golek menak investigated and used as research source is wayang golek menak with Yogyakarta style developing in Sentolo area, Gunung Kidul.

Serat menak was later composed in the $18^{\text {th }}$ century, during kapujanggan period in Surakrta, Yasadipura compoled the composition of Serat Menak from Menak Kartasura [21]. Sources of the story in the composed Serat Menak by Yasadipura (then known as Menak Yasadipura), are expanded. It is then compiled in terms of tembang macapat because in Kraton Surakata period, literary works was frequently written in terms of serat, which contains the collection of tembang macapat. This Serat Menak told about Amir Hamzah, a story from Turkey [22]. Figures performed in wayang golek menak are Wong Agung Jayengrana, Umarmaya, Umarmadi, Adaninggar, Kelaswara, Patih Bestak, dan others. Each part of the story delivered, become readers' and audiences' reflection to be able to get life values, which are useful for an effot to construct and develop their personalities.

\subsection{Development of Golek Menak with Yogyakarta Stye}

The duration of wayang golek menak shows has developed many times. At first, the show needs six to seven hours. In 1975s, the show with the duration of two hours appeared, perfomed for foreign tourists. Another development is the existence of 60-120 minutes duration show, adjusted to tourists' requests who will watch the show. Menwhile, this study compiles Wayang Golek Menak show with applying pakeliran garap padat concept in terms of scene structure garap, accompanied garap, garap sabet, and garap singgit with 60 menit show duration.

The stage of the show is made so dalang can move as needed in the scence by building portable stage that can be moved with using wheels. This stage is more than one. They are organized to be changeable and adjusted to the need of certain scene that represent the imaginative parts of the show. This staging concept is selected because this study intends to combine conventional wayang golek show staging and contemporary wayang golek menak show staging as the development of the original wayang golek show [24] [25]. It is expected that this study can introduce general staging of wayang golek show and the special one in Wayang Golek Menak show, so their differences will be recognized. This study also carries out the innovation of language use. In general, Wayang Golek Ménak Sentolo uses Javanese language with 
pedalangan (puppetry) Yogyakarta. In this study, Wayang Golek Menak chooses Indonesian language. Besides, it represents two sizes of wayang golek puppet, namely conventional size changed with new clothes, and large size with average height of $75 \mathrm{~cm}$ and weight of 750 gram to make audiences's sight clear in watching the figures showed. The main material of puppet head is Chinese albizzia due to its lightness. The material for puppet body is a second-hand paper from cement wrap, molded in hollows, so that gives cheeper production, produce lightweight puppet, and decrease paper waste [26].

From the staging, there is the change of Wayang Golek Menak play technique. Wayang Golek Ménak Sentolo can be played by sitting down and facing the stage, in which the show can be watched from both the front and behind dalang [13]. Wayang Golek Menak shows are deliberately planned to only be watched in front of dalang. Dalang plays a role in moving puppets, either sitting down or standing position, adjusted to scene needs. Each figure of wayang puppets are played by a dalang or two, depending on the needed atmosphere in the scene.

The cinematography approach is also applied in wayang golek menak show by using dubbing technique as figures' voice acting. Dialogues and narration are perfomed by voice actors, consisting of some persons play certain figures with reference to the need of figures perfomed [27]. To decrease the number of voice actors, a person probably plays more than one figure, depending on his/her ability in voice acting. Voice actors play figures with reference to sexes, female figures are played by female voice actors, and vise versa.

Music elements also important parts in wholly building the show staging [28]. Music accompaniment used with reference to traditional music by selecting some instruments or ricikan gamelan collaborated with wind and string instruments, and non-traditional string instruments. To accompany wayang golek menak, the instruments needed are Bonang Penembung, Bonang Barung, Gendèr, Gendèr Penerus, Demung, Saron, Kempul, dan Gong as well as non-traditional wind instrument, guitar, fiddle, and some kendang.

Lighting technique in wayang golek menak show used stage lamp with $5.000 \mathrm{~W}$ located in some spots that can give appropriate lighting for the scenes performed, and more focus on some stage blocking needed. This lighting technique adopts the one for theatre [29]. The selection of this technique aims to limit the space of the show so that do not occupy the wider space that make wayang puppets unclear.

\section{CONCLUSION}

Puppet arts developing in community are widely varied, including wayang kulit purwa, wayang klithik, and wayang golek. Wayang golek is considered as a convesntional art because it developed in $1990-2000$ s. The development of wayang golek is required to attract audiences' interest and attention. It has been done by changing stories performed, from Ramayana and Mahabarata epic stories to stories from Serat Menak. Wayang golek menak is also a visualization media of Serat Menak. It has been developed from the original one, in terms of shorter duration, different language use, performance technique with using theater approach through modern blocking and lighting, dubbing technique for figure voice acting as animation films, portable stange to be easily moved, and different form of wayang golek in terms of size and materials. This development and new form of wayang golek menak is expected to be more acceptable in modern community.

\section{REFERENCES}

[1]. J. Sutopo, September, “Alternating Least Square Method for Decomposing Dance Golek Menak Tensor Data”, Journal of Physics: Conference Series, 1090 (1), pp. 012057, 2018. 
[2]. C. Chia, "Negotiation" Between a Religious Art Form and the Secular State: Chinese Puppet Theater in Singapore and the Case Study of Sin Hoe Ping", Asian Ethnology, 76(1), pp. 117-144, 2017.

[3]. F. Butler and S. Pickering Jr, "Big Bird of Sesame Street: An Interview", The Antioch Review, 75(3), pp. 249-260, 2017.

[4]. J. McCormick, "Puppet Theatre in Italy", Móin-Móin-Revista de Estudos sobre Teatro de Formas Animadas, 1(02), pp. 053-065, 2018.

[5]. M. Nitsche and C. Eng, Making Puppet Circuits. In Interactivity, Game Creation, Design, Learning, and Innovation, United Kingdom: Springer Cham, 2018.

[6]. M. I. Cohen, "Wayang in Museums: The Reverse Repatriation of Javanese Puppets", Theatre Journal, 69(3), pp. 361-381, 2017.

[7]. D. Rahmawanto and F. X. Rahyono, "Strategies for Establishing Harmony in Javanese Face-to-face Dialog in Purwa Shadow Puppet Performances", 3L: Language, Linguistics, Literature ${ }^{\circledR}, 25(1), 2019$.

[8]. I. N. Sedana and K. Foley, "Ancestral Deliverance and Puppet Performance: Mulian Rescues his Mother and Bima Goes to Heaven", Asian Theatre Journal, 35(1), pp. 85-98, 2018.

[9]. J. Mrázek, Puppet Theatre in Contemporary Indonesia: New Approach to Performance Events, USA: University of Michigan, 2003.

[10]. C. Gray and J. Malins, Visualizing Research: A Guide to the Research Process in Art and Design, New York: Routledge, 2016.

[11]. R. Long, Javanese Shadow Theatre: Movement and Characterization in Ngayogyakarta Wayang Kulit, Michigan: UMI Research Press, 1982.

[12]. M. A. Ishiguro, "Malay Theatre: Intangible Cultural Heritage and Islam: Wayang Kulit Kelantan and Mak Yong by Kathy Foley and Patricia Hardwick, and: Tradition in Transition: Intangible Heritage in South and Southeast Asia", Asian Theatre Journal, 35(1), pp. 216-221, 2018.

[13]. A. S. Nalan, "Asep Sunandar Sunarya: Dalang of Wayang Golek Sunda (19552014)", Asian Theatre Journal, 33(2), pp. 264-269, 2016.

[14]. M. I. Cohen, "Wayang in Jaman Now: Reflexive Traditionalization and Local, National and Global Networks of Javanese Shadow Puppet Theatre", Theatre Research International, 44(1), pp. 40-57, 2019.

[15]. J. Mrázek, Wayang and Its Doubles: Javanese Puppet Theatre, Television and the Internet, Singapore: NUS Press, 2019.

[16]. A. J. Schauf and M. E. Varela, "Searching for Hidden Bridges in Co-Occurrence Networks from Javanese Wayang Kulit”, Journal of Historical Network Research, 2(1), pp. 26-52, 2018.

[17]. G. S. Yousof and K. K. Khor, "Wayang Kulit Kelantan: A Study of Characterization and Puppets", Asian Theatre Journal, 34(1), pp. 1-25, 2017.

[18]. B. W. Setyawan and K. Saddhono, "Ceprotan Performing Art: A Traditional Folkart Based on Urband Legend", Harmonia: Journal of Arts Research and Education, 18(1), pp. 6773, 2018.

[19]. G. O. F. Parikesit, “3D Wayang Kulit: Traditional Shadow Puppetry Meets Modern Display Technology”, International Journal of Arts and Technology, 9(2), pp. 162-172, 2016.

[20]. P. I. Fauzan and A. K. Fata, "Serat Cabolek, Sufism Book or Ideology Documents of Javanese Priyayi?” Journal El Harakah, 20(1), pp. 65, 2018. 
[21]. F. Wijanarko, "Serat Dahor Palak, Sastra Islam Abad XVII", SHAHIH: Journal of Islamicate Multidisciplinary, 2(1), pp. 37-52, 2017.

[22]. F. Jabali, "Malay Annals on Persia: The Question of Royal Identity", Media Syari'ah, 15(1), pp. 43-52, 2017.

[23]. S. L. Yu, "The Orphan of Zhao: Chinese Revenge Drama and European Adaptations", Comparative Literature Studies, 55(1), pp. 144-171, 2018.

[24]. A. Aziz, K. Komalasari, and I. S. Masyitoh, "Semiotics of Wayang Golek Lingkung Seni Giriharja's Show as a Learning Source of Civic Education", Jurnal Ilmiah Pendidikan Pancasila dan Kewarganegaraan, 2(2), pp. 91-97, 2017.

[25]. J. Goodlander, "The Routledge Companion to Puppetry and Material Performance ed. by Dassia N. Posner, Claudia Orenstein, and John Bell”, Asian Theatre Journal, 33(1), pp. 214-216, 2016.

[26]. H. Leli, R. Roni, M. S. Yuliariatiningsih, and A. Sutini, "The Role of Wayang Golek as Prototype Model in Building Mega skill Characters of Children" Proceeding 3rd International Conference on Early Childhood Education (ICECE), 2016.

[27]. D. Izario, B. Izario, D. Castro, and Y. Iano, "Face Recognition Techniques using Artificial Intelligence for Audio-Visual Animations", Set International Journal of Broadcast Engineering, 3 (5), 2018.

[28]. M. H. Tsai and A. T. E. Hapsari, "Usage of 12 Animation Principles in The Wayang Kulit Performances", Jurnal Telematika, 6(1), 2015.

[29]. K. Foley and Z. A. Latiff, "Modern Teater and Traditional Genres in Malaysia and Indonesia", Asiatic: IIUM Journal of English Language and Literature, 11(2), pp. 46-63, 2017. 